\title{
Gaseous Elemental Mercury (GEM) in the Mexico City Metropolitan Area
}

\author{
Ofelia Morton-Bermea ${ }^{1}$ (D) Benedetto Schiavo ${ }^{1}$ (i) - Elias Salgado-Martínez ${ }^{1} \cdot$ Manuel Alejandro Almorín-Ávila $^{2}$. \\ Elizabeth Hernández-Álvarez ${ }^{1}$
}

Received: 16 January 2021 / Accepted: 9 June 2021 / Published online: 10 July 2021

(c) The Author(s), under exclusive licence to Springer Science+Business Media, LLC, part of Springer Nature 2021

\begin{abstract}
This paper presents atmospheric gaseous elemental mercury (GEM) data recorded during two short-term monitoring surveys in the Mexico City Metropolitan Area (MCMA) at 12th May 2019 and at 22nd May 2020, during conditions of low and high human activity respectively. Results, although they are limited, can be considered as the representative range of exposure to GEM of the inhabitants of MCMA; differences in results reveal the impact of human activities on GEM background levels (2.53 and $3.76 \mathrm{ng} \mathrm{m}^{-3}$, respectively). GEM concentrations and their spatial distribution does not allow for the identification of important industrial sources and do not reach intervention pollution levels. The activity of the Popocatépetl volcano is not likely to have an effect on GEM in the MCMA. In spite the evident decrease in GEM concentrations compared with data previously reported, monitoring must be carried out routinely given Mexico's participation in the Minamata Convention on Mercury.
\end{abstract}

Keywords GEM $\cdot$ Mexico City $\cdot$ Atmospheric pollution $\cdot$ Mercury spatial distribution $\cdot$ Minamata Convention

It is acknowledged that mercury $(\mathrm{Hg})$ pollution levels in urban areas is seriously affected by human activities. This increase is attributed mainly to fossil fuel combustion, uncontrolled industrial emissions, and mismanagement of municipal and waste (Duan et al. 2017; Zhao et al. 2018).

Recent research has reported high mercury $(\mathrm{Hg})$ concentrations in the environment worldwide, as well as the associated health risks for humans (Shahid et al. 2020; Morton-Bermea et al. 2021). Mercury pollution has thus attracted a great deal of attention from governmental and regulatory bodies that are concerned with the restriction of

Ofelia Morton-Bermea

omorton@geofisica.unam.mx

Benedetto Schiavo

benedetto@atmosfera.unam.mx

Elias Salgado-Martínez

eliassalgado@uagro.mx

Manuel Alejandro Almorín-Ávila

alealmorin@gmail.com

1 Instituto de Geofísica, Universidad Nacional Autónoma de México, Mexico, DF 04150, Mexico

2 Facultad de Química, Universidad Nacional Autónoma de México, Mexico, DF 04150, Mexico anthropogenic $\mathrm{Hg}$ emissions globally, culminating in the Minamata Convention on Mercury of the United Nations Environment Program (UNEP), signed in October 2013 in Minamata, Japan (Gibb and O'Leary 2014). This Convention refers to an international regulatory mechanism aimed at decreasing environmental $\mathrm{Hg}$ loads and designed "to protect human health and the environment from anthropogenic emissions and release of mercury and mercury compounds".

Despite the global increase of $\mathrm{Hg}$ in the environment over the last decades, a few recent reports have shown reductions in environmental metal concentrations. Therefore, a gradual decline of environmental pollution can be expected due to the financial crisis that impacted the industrial production and use of fossil fuels, combined with the implementation of pollution abatement strategies (Chen et al. 2014; Cusack et al. 2012; Querol et al. 2014; Zhang et al. 2016). Understanding the impact of such crises on atmospheric $\mathrm{Hg}$ behavior in urban areas is essential for the successful implementation of the Minamata Convention.

Gaseous elemental mercury (GEM) has a long residence time in the atmosphere, ranging from 0.5 to two years. It is the most predominant form of total gaseous mercury (TGM), with a representation of over $95 \%$ (Fu et al. 2010). On the other hand, reactive gaseous mercury (RGM) and particulate 
mercury (PHg) have atmospheric lifetimes of days to weeks. Measurements of atmospheric GEM, RGM and PHg concentration in urban areas generally fall within the range of 2.0-5.8 $\mathrm{ng} \mathrm{m}^{-3}, 5-10 \mathrm{pg} \mathrm{m}^{-3}$ and $10-100 \mathrm{pg} \mathrm{m}^{-3}$, respectively (Fu et al. 2010). The study of the spatial distribution of pollutants in urban environments is especially important for identifying hot-spot areas and to assess potential pollution sources. Geochemical maps generated using geographic information systems (GIS) enable the visualization of information in a geographic context in order to formulate appropriate proactive measures.

This study has two main objectives: (1) To compare GEM data obtained from two short-term monitoring surveys of GEM in the Mexico City Metropolitan Area (MCMA) to analyze their behavior under different circumstances of human activity. The first survey was conducted on 12th May 2019 during a period of extremely low human activity and the second on 22nd May 2020 during apparent higher human activity conditions (vehicular traffic, commercial activity, etc.). (2) To evaluate the trend of $\mathrm{Hg}$ contamination in MCMA by comparing GEM concentration recorded during this study with previously reported data. The assessment of atmospheric $\mathrm{Hg}$ under these circumstances is important for the proposal of efficient regulatory strategies, which is relevant given Mexico's commitments within the Minamata Convention.

\section{Materials and methods}

The present study is focused on the Mexico City Metropoli$\tan$ Area (MCMA). The urban population of the area studied is $\sim 21$ million. With a high population density of 6000 inhabitants $/ \mathrm{km}^{2}$, it is one of the world's largest megacities and the most populated city in North America. The mean annual temperature is $16{ }^{\circ} \mathrm{C}$ and the average annual precipitation is $660 \mathrm{~mm}$. Local seasons are strongly pronounced: rainy season (May-October), cool dry season (November to February) and warm dry season (March-April).

The MCMA has been subjected to rapid and uncontrolled urbanization. The potential sources of pollutants are assumed to be petroleum processing, the production of iron material, manufacturing, coal combustion, and commercial and automobile exhaust. Important industries and industrial dumps are located principally in the north: the Tula Industrial complex, the Comisión Federal de Electricidad (CFE) thermoelectric plant, and the Petróleos Mexicanos (Pemex) refinery.

Atmospheric GEM was analyzed using an automated real-time atomic absorption spectrometer (Lumex-RA $915 \mathrm{M}$ ) in standard monitoring mode, by pumping air at $101 \mathrm{~min}^{-1}$ (Sholupov et al. 2004). The GEM detection limit is $0.5 \mathrm{ng} \mathrm{m}^{-3}$, and its zero-baseline correction occurs every
$60 \mathrm{~min}$. The instrument has a high data-acquisition frequency (minimum time between sampling: one second) and can also be adjusted to generate average data as frequently as every $30 \mathrm{~s}$. The analyzer does not require special carrier gases. A zero correction was applied (every $30 \mathrm{~min}$ ) during the measurements to reset the baseline. Instrument accuracy is about $22 \%$.

The trajectory of the monitoring route was carefully designed to include commercial, residential, and industrial areas potentially exposed to different pollution sources and traffic intensities. Geographic location data was obtained using a Garmin GPS Map 60CSX device. We used Surfer Golden Software to interpolate data by employing a polynomial method and mapping Hg concentrations. Two mobile surveys were carried out approximately one year apart, on 12th May 2019 and 22nd May 2020. The aim of carrying out the exact same trajectory was partially hindered although it was $90 \%$ achieved.

\section{Results and discussion}

Descriptive statistics of GEM measurements recorded during both road surveys in the MCMA are presented in Table 1.

The first survey consists of 10,993 GEM data points collected over a period of five hours on 12th May 2019. GEM mean concentration was $3.80 \pm 1.34 \mathrm{ng} \mathrm{m}^{-3}$ and the highest concentration was $11.9 \mathrm{ng} \mathrm{m}^{-3}$. Background values were calculated at $2.53 \pm 0.93 \mathrm{ng} \mathrm{m}^{-3}$. The background GEM level during both surveys represents the average data recorded during the measurement time when no anthropogenic impact was evident. GEM background values for the studied area are defined by the prevailing human activity conditions.

The second car transect (22nd May 2020) includes 12,000 GEM measurements. Concentrations were higher than those recorded in the first survey Mean concentration is estimated

Table 1 GEM concentration and meteorological parameters recorded during both monitoring surveys

\begin{tabular}{lllll}
\hline & Min & Max & Mean & SD \\
\hline 1st survey May 12th 2019 & $\mathrm{ng} \mathrm{m}^{-3}$ & & & \\
GEM & 0.50 & 11.90 & 3.80 & 1.80 \\
GEM background & - & - & 2.53 & 0.93 \\
T $\left({ }^{\circ} \mathrm{C}\right)$ & 12.21 & 26.16 & 20.52 & 4.33 \\
Rh $(\%)$ & 18.60 & 75.46 & 43.89 & 16.00 \\
2nd survey May 22th 2020 & $\mathrm{ng} \mathrm{m}^{-3}$ & & & \\
GEM & 0.50 & 32.60 & 5.04 & 2.95 \\
GEM background & -- & -- & 3.76 & 1.79 \\
T $\left({ }^{\circ} \mathrm{C}\right)$ & 12.53 & 27.09 & 21.01 & 3.84 \\
Rh $(\%)$ & 21.17 & 56.66 & 33.80 & 7.95 \\
\hline
\end{tabular}


at $5.04 \pm 2.95 \mathrm{ng} \mathrm{m}^{-3}$. Background levels are calculated at $3.76 \pm 1.79 \mathrm{ng} \mathrm{m}^{-3}$.

The intensity of human activity observed during both surveys was noticeably different. The first survey was carried out on a Sunday during a period of extremely low human activity and the low traffic intensity was especially noticeable during the car transect. On the other hand, the second survey was conducted on a Friday during a high level of human activity (vehicular traffic, commercial activity, etc.) notwithstanding the human movement restrictions in place due to the coronavirus pandemic. In the northern hemisphere, the GEM mean background has been estimated at $\sim 2 \mathrm{ng} \mathrm{m}^{-3}$ (Sprovieri et al. 2010). The regional GEM background outside of the MCMA (measured at both a rural location and a Pacific coast location) was determined to be $1.4 \pm 0.1 \mathrm{ng} \mathrm{m}^{-3}$ (de la Rosa et al. 2006), which is not statistically different than the western northern hemisphere background.

When analyzing the disparities between the background values in both studies it is important to acknowledge the differences in traffic conditions. As mentioned above, the more intense traffic conditions during the second survey, not only in the analyzed route but in the whole metropolitan area, may be considered responsible for the increase in the background value in the study area.

Local variations of GEM recorded during the first car survey are shown in Fig. 1a. While a considerable proportion of the measured values in the southern and western areas of the analyzed transect are within the range of the background values, concentrations measured in the northern region reach enrichment factors of up to four times those of the background levels, with a maximum of $11.9 \mathrm{ng} \mathrm{m}^{-3}$, which may be attributed to possible focal industrial sources. Figure 1 presents a relatively uniform GEM distribution in the study area during the second survey. There is no anomalous increase in the northern region, as opposed to the first transect. However, two short-lived episodes of increased GEM concentrations were recorded in the east and in the center of the study area, reaching 25 and $30 \mathrm{ng} \mathrm{m}^{-3}$, respectively.

The spatial distribution and enrichment of GEM in both transects were compared with the results of a study previously reported by Rutter et al. (2009). In this study, GEM input to the NE part of the MCMA is attributed to anthropogenic point sources in and around the urban area, enhanced by the prevailing wind conditions. For a monitoring study carried out in five points of the MCMA, Morton-Bermea et al. (2018) report that the highest $\mathrm{Hg}$ concentrations in $\mathrm{PM}_{2.5}$ samples were collected in the NW part of the urban area. In addition, they report $\mathrm{Hg}$ spatial distributions in agreement with the location of important industrial facilities in the northern urban area and with flow direction during the sampling days.

The prevailing wind direction in the MCMA during both monitoring days of this study is shown in Fig. 2. The hourly average of $24 \mathrm{~h}$ was taken from five atmospheric stations located within the metropolitan area. The directions S-N and SW-NE, predominant in this work, do not correspond to the wind conditions observed during the studies of Rutter et al. (2009) and Morton-Bermea et al. (2018). Thus, the measured enrichment of GEM in both the first and second surveys cannot be attributed to industrial emissions in the north of the MCMA. As there is no evident $\mathrm{Hg}$ contribution from anthropogenic focal sources around MCMA during the study period, the short-lived episodes of higher GEM concentrations present during the first and second transects can be linked to local sources.
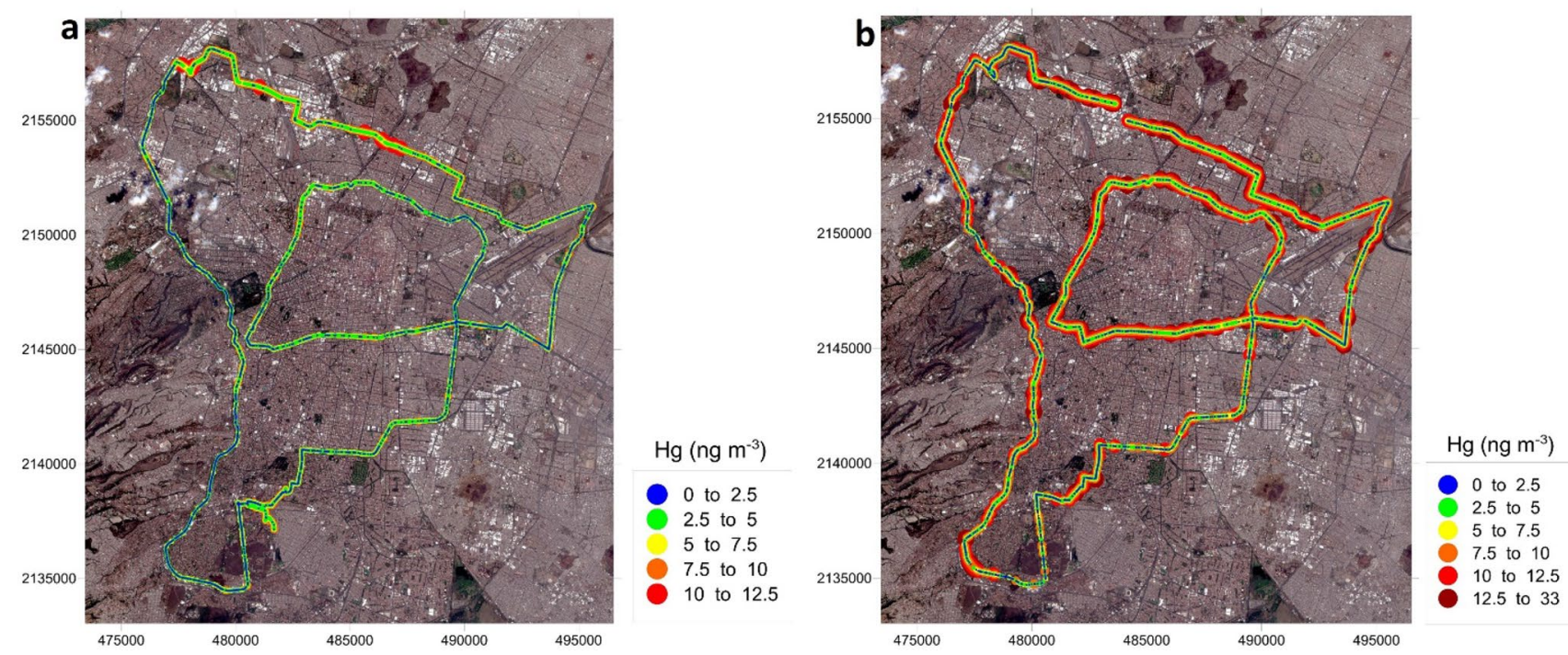

Fig. 1 GEM concentration recorded during both road surveys in MCMA: a May 12th 2019 and b on May 22th 2020 

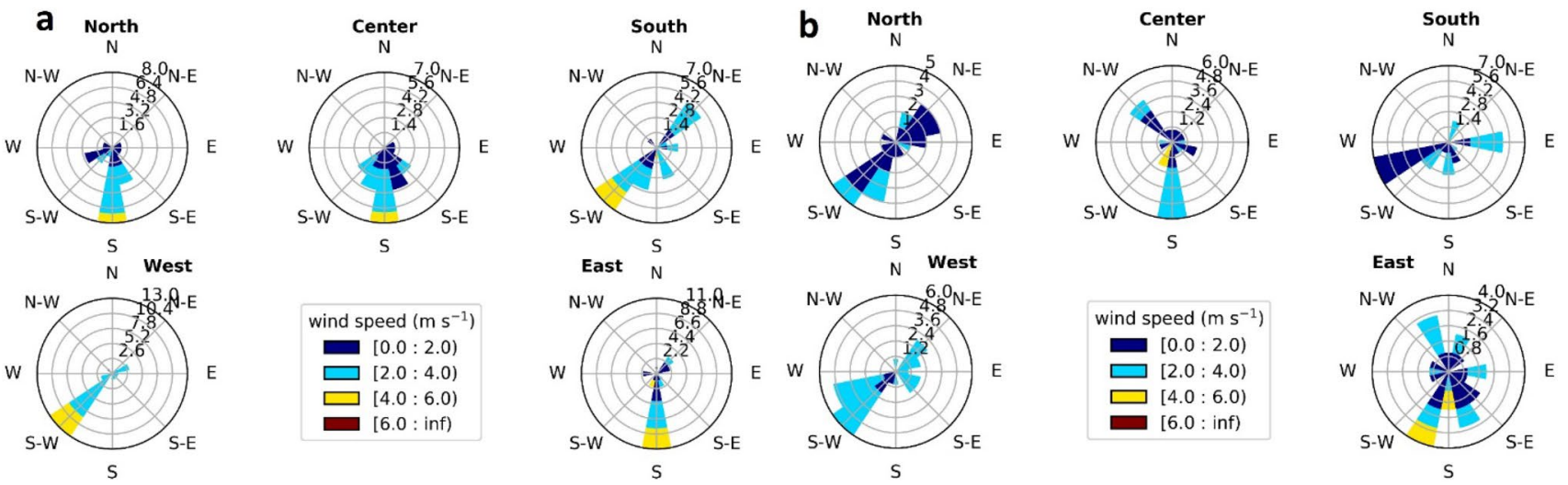

Fig. 2 Wind roses wind direction generated with hourly average data of $24 \mathrm{~h}$ taken from five stations located within MCMA: a for May 12th 2019; b for May 22th 2020

A deeper assessment of the effects of wind on GEM atmospheric dispersion allowed us to weigh the sources responsible for the high GEM concentrations registered in this study. Several reports indicate, through means of a backward-trajectory model analysis, that elevated GEM content was transported to the sampling site from regional sources. A Hysplit backward trajectory model (Stain et al., 2015; Rolph et al. 2017) was applied to obtain information about the possible contribution from atmospheric pollutants transported to the sampling site from regional sources (Fig. $\mathrm{S} 1$ ). The model was adapted to the wind conditions of the MCMA during the sampling days. The analysis could not determine the contribution of regional $\mathrm{Hg}$ sources to the MCMA for the days studied.

Rutter et al. (2009) consider the emissions from the Popocatépetl volcano to be a possible source responsible for the increase of GEM in the southern part of the MCMA and suggest the need to quantify its impact. Recently, Schiavo et al. (2020a) reported an estimate of Popocatépetl Hg flux during a particularly explosive phase of the volcano. GEM data registered at a fixed location $11 \mathrm{~km}$ from the crater showed maximum values of around $5 \mathrm{ng} \mathrm{m}^{-3}$ during periods of high volcanic activity. Furthermore, in a later study which covered a total distance of $129 \mathrm{~km}$ around the volcano, Schiavo et al. (2020b) report that most registered GEM concentrations are between 2.2 and $3.3 \mathrm{ng} \mathrm{m}^{-3}$, which corresponds to the typical background values estimated in the area. These measurements were taken at $7-18 \mathrm{~km}$ from the crater in inhabited areas. The highest concentrations recorded, about $10 \mathrm{ng} \mathrm{m}^{-3}$, can be interpreted as being a consequence of wind and plume direction and the proximity of the sampling point to the crater $(\sim 7 \mathrm{~km})$, and/or the dilution of $\mathrm{Hg}$ in the area after a considerably large explosion. Overall, the dilution of GEM away from the crater is strong and suggests that the volcanic activity of Popocatépetl is not likely to influence GEM concentrations in the MCMA, located $80 \mathrm{~km}$ away.
However, if the emission is strong enough and the wind direction is favorable, this activity could affect the MCMA.

Differences in spatial GEM behavior between both surveys could not be attributed to changes in wind conditions between both studies. Nor could an important contribution from the Popocatépetl volcano be identified. These factors highlight the impact of the anthropogenic conditions related to daily life in the MCMA on GEM concentrations. This is supported by the difference in traffic conditions during both car surveys. In addition, abnormal increases that may be attributed to major industrial sources are identified.

The differences in GEM concentrations obtained in this study $\left(3.80 \pm 1.34 \mathrm{ng} \mathrm{m}^{-3}\right.$ and $\left.5.04 \pm 0.92 \mathrm{ng} \mathrm{m}^{-3}\right)$ and those obtained by Rutter et al. $\left(7.2 \pm 4.8 \mathrm{ng} \mathrm{m}^{-3}\right)$ indicate a decrease in GEM concentrations in the MCMA between 2006 and 2019/2020. This can be interpreted as a positive result of the implementation of local regulatory measures to control Hg emissions. However, it must be noted that Rutter et al. (2009) report $\mathrm{Hg}$ concentrations recorded in a unique sampling location, which corresponds to the area where the highest GEM was recorded during the first transect of the present study.

The most obvious difference in human activity between these two dates was the vehicular traffic. The human activity observed in these two dates can be considered as the extreme conditions in the daily life of the urban area. Hence, the results of this study, although they are limited to two sampling days, can be considered as a representative range of exposure to GEM of the inhabitants of the urban area. GEM concentrations did not reach $200 \mathrm{ng} \mathrm{m}^{-3}$, a figure established by the World Health Organization (WHO 2000) as a tolerable concentration for long-term inhalation exposure, in either monitoring route.

Monitoring programs of GEM must be carried out routinely in this area in order to evaluate the possible influence of other meteorological and emission conditions. This 
is important given Mexico's participation in the Minamata Convention on Mercury.

Supplementary Information The online version contains supplementary material available at https://doi.org/10.1007/s00128-021-03293-6.

Acknowledgements Lumex RA-915 M mercury analyzer was purchased with the financial support of the Project 268074 GEMEX Cooperación Mexico-Europa para la investigación de sistemas geotérmicos mejorados y sistemas geotérmicos super calientes. The authors acknowledge the NOAA Air Resources Laboratory (ARL) for the provision of the HYSPLIT transport and dispersion model and/or READY website (https://www.ready.noaa.gov) used in this publication.

\section{References}

Chen Y, Schleicher N, Chen Y, Chai F, Norra S (2014) The influence of governmental mitigation measures on contamination characteristics of $\mathrm{PM}_{2.5}$ in Beijing. Sci Total Environ 490:647-658. https:// doi.org/10.1016/j.scitotenv.2014.05.049

Cusack M, Alastuey A, Pérez N, Pey J, Querol X (2012) Trends of particulate matter $\left(\mathrm{PM}_{2.5}\right)$ and chemical composition at a regional background site in the Western Mediterranean over the last nine years (2002-2010). Atmos Chem Phys 12:8341-8357. https://doi. org/10.5194/acp-12-8341-2012

de la Rosa DA, Velasco A, Rosas A, Volke-Sepulveda T (2006) Total gaseous mercury and volatile organic compounds measurements at five municipal solid waste disposal sites surrounding the Mexico City Metropolitan Area. Atmos Environ 40:2079-2088. https://doi.org/10.1016/j.atmosenv.2005.11.055

Duan L, Wang X, Wang D, Duan Y, Cheng N, Xiu G (2017) Atmospheric mercury speciation in Shanghai, China. Sci Total Environ 578:460-468. https://doi.org/10.1016/j.scitotenv.2016.10.209

Fu XW, Feng X, Dong ZQ, Yin RS, Wang JX, Yang ZR, Zhang H (2010) Atmospheric gaseous elemental mercury (GEM) concentrations and mercury depositions at a high-altitude mountain peak in south China. Atmos Chem Phys 10:2425-2437. https://doi.org/ 10.5194/acp-10-2425-2010

Gibb H, O'Leary KG (2014) Mercury exposure and health impacts among individuals in the artisanal and small-scale gold mining community: a comprehensive review. Environ Health Perspect 122:667-672. https://doi.org/10.1289/ehp.1307864

Morton-Bermea O, Garza-Galindo R, Hernández-Álvarez E, OrdoñezGodínez SL, Amador-Muñoz O, Beramendi-Orosco L, Miranda J, Rosas-Pérez I (2018) Atmospheric $\mathrm{PM}_{2.5}$ mercury in the metropolitan area of Mexico City. B Environ Contam Tox 100:588-592. https://doi.org/10.1007/s00128-018-2288-6

Morton-Bermea O, Castro-Larragoitia J, Álvarez ÁAA, Pérez-Rodríguez RJ, Leura-Vicencio A, Schiavo B, Álvarez EH (2021) Mercury in blood of children exposed to historical residues from metallurgical activity. Expos Health. https://doi.org/10.1007/ s12403-021-00382-z
Querol X, Alastuey A, Pandolfi M, Reche C, Perez N, Minguillón MC, Moreno T, Viana M, Escudero M, Orico A, Pallarés M, Rein F (2014) 2001-2012 trends on air quality in Spain. Sci Total Environ 490:957-969. https://doi.org/10.1016/j.scitotenv.2014.05.074

Rolph G, Stein A, Stunder B (2017) Real-time environmental applications and display system: ready. Environ Model Softw 95:210 228. https://doi.org/10.1016/j.envsoft.2017.06.025

Rutter AP, Snyder DC, Stone EA, Schauer JJ, Gonzalez-Abraham R, Molina LT, Márquez C, Cárdenas B, de Foy B (2009) In situ measurements of speciated atmospheric mercury and the identification of source regions in the Mexico City Metropolitan Area. Atmos Chem Phys 9:207-220. https://doi.org/10.5194/acp-9-207-2009

Shahid M, Khalid S, Bibi I, Bundschuh J, Niazi NK, Dumat C (2020) A critical review of mercury speciation, bioavailability, toxicity and detoxification in soil-plant environment: ecotoxicology and health risk assessment. Sci Total Environ 711:134749. https://doi. org/10.1016/j.scitotenv.2019.134749

Schiavo B, Morton-Bermea O, Salgado-Martinez E, Arellano J, Hernández-Álvarez E (2020a) Estimates of mercury flux and temporal variability of $\mathrm{Hg} / \mathrm{SO} 2$ ratio in the plume of Popocatépetl volcano (Mexico). J S Am Earth Sci 102614. https://doi.org/10. 1016/j.jsames.2020.102614

Schiavo B, Morton-Bermea O, Salgado-Martinez E, Hernández-Álvarez E (2020b) Evaluation of possible impact on human health of atmospheric mercury emanations from the Popocatépetl volcano. Environ Geochem Hlth 42:3717-3729. https://doi.org/10.1016/j. jsames.2020.102614

Sholupov S, Pogarev S, Ryzhov V, Mashyanov N, Stroganov A (2004) Zeeman atomic absorption spectrometer RA-915 + for direct determination of mercury in air and complex matrix samples. Fuel Process Technol 85:473-485. https://doi.org/10.1016/j. fuproc.2003.11.003

Sprovieri F, Pirrone N, Ebinghaus R, Kock H, Dommergue A (2010) A review of worldwide atmospheric mercury measurements. Atmos Chem Phys 10:8245-8265. https://doi.org/10.5194/ acp-10-8245-2010

Stein AF, Draxler RR, Rolph GD, Stunder BJB, Cohen MD, Ngan F (2015) NOAA's HYSPLIT atmospheric transport and dispersion modeling system. Bull Amer Meteor Soc 96:2059-2077. https:// doi.org/10.1175/BAMS-D-14-00110.1

WHO (2000) Air quality guidelines for Europe, vol 91, 2nd edn. WHO Regional Publications, European Series Geneva, pp 157-162

Zhang H, Wang S, Hao J, Wang X, Wang S, Chai F, Li M (2016) Air pollution and control action in Beijing. J Clean Prod 112:15191527. https://doi.org/10.1016/j.jclepro.2015.04.092

Zhao L, Xu L, Wu X, Zhao G, Jiao L, Chen J, Hong Y, Deng J, Chen Y, Yang K, Hu G, Yu R (2018) Characteristics and sources of mercury in precipitation collected at the urban, suburban and rural sites in a city of Southeast China. Atmos Res 211:21-29. https:// doi.org/10.1016/j.atmosres.2018.04.019

Publisher's Note Springer Nature remains neutral with regard to jurisdictional claims in published maps and institutional affiliations. 